\title{
MIĘDZYNARODOWA AKTYWNOŚĆ WOJEWÓDZTWA PODLASKIEGO
}

Aktywność zagraniczna województwa podlaskiego w zmieniającej się rzeczywistości europejskiej jest ciekawym przykładem funkcjonowania struktur samorządu terytorialnego. Wieloletnie doświadczenie autorów niniejszego artykułu, pracujących na co dzień w Departamencie Współpracy z Zagranicą i Promocji Urzędu Marszałkowskiego Województwa Podlaskiego, pozwala na prezentację prowadzonych przez region działań zmierzających do budowania wizerunku województwa na arenie międzynarodowej.

\section{Podstawy prawne}

Art. 3 Konstytucji RP stanowi, że Rzeczpospolita Polska jest państwem unitarnym. Oznacza to, że nie istnieją w jej obrębie żadne autonomiczne jednostki terytorialne, a co za tym idzie, Polska stanowi jeden podmiot stosunków międzynarodowych. Zgodnie z tym, niemożliwe jest prowadzenie niezależnej, odrębnej działalności międzynarodowej przez jednostki samorządu terytorialnego, w tym województwa. Wszelka zewnętrzna aktywność województw musi być podporządkowana i zgodna z wytycznymi polityki zagranicznej państwa.

Ramy współpracy zagranicznej województw określa art. 172 ust. 2 Konstytucji RP. Przewiduje on możliwość przystępowania do międzynarodowych zrzeszeń społeczności lokalnych i regionalnych oraz współpracy ze społecznościami lokalnymi i regionalnymi innych państw. Na podstawie delegacji ustawowej zawartej w art. 172 ust. 3 Konstytucji RP zasady realizacji współpracy międzynarodowej woje-

\footnotetext{
* Dyrektor Departamentu Współpracy z Zagranicą i Promocji Urzędu Marszałkowskiego Województwa Podlaskiego w Białymstoku.

** Kierownik Referatu Współpracy z Zagranicą w Departamencie Współpracy z Zagranicą i Promocji Urzędu Marszałkowskiego Województwa Podlaskiego w Białymstoku.

*** Zastępca Dyrektora Departamentu Współpracy z Zagranicą i Promocji Urzędu Marszałkowskiego Województwa Podlaskiego w Białymstoku.
} 
wództw regulują przepisy rozdziału 6 Ustawy z dnia 5 czerwca 1998 roku o samorządzie województwa. ${ }^{276}$

Zgodnie z postanowieniami art. 75 Ustawy o samorządzie województwa podstawą zagranicznej aktywności są Priorytety wspótpracy zagranicznej województwa - uchwała sejmiku województwa wymagająca uprzedniej zgody ministra spraw zagranicznych. Uchwała ta ma fundamentalne znaczenie, gdyż wszelkie umowy i porozumienia o współpracy, a także inicjatywy zagraniczne województwa muszą być zgodne z określonymi w niej priorytetami. Art. 76 ust. 1 Ustawy o samorządzie województwa stanowi odwołanie i jednocześnie rozwinięcie zasady unitarności państwa. Przewiduje on, że współpraca zewnętrzna województwa musi odbywać się w granicach jego zadań i kompetencji oraz pozostawać w zgodzie z prawem wewnętrznym, polityką zagraniczną państwa i jego międzynarodowymi zobowiązaniami.

Priorytety współpracy zagranicznej województwa podlaskiego określa Uchwała $\mathrm{Nr}$ XXXVII/480/06 Sejmiku Województwa Podlaskiego z dnia 10 kwietnia 2006.277 Uchwała precyzuje cele współpracy zagranicznej regionu, które obejmują:

a) rozwijanie dobrosąsiedzkich stosunków i partnerskiej współpracy z regionami państw sąsiadujących;

b) współpracę z regionami państw Unii Europejskiej, w tym realizację wspólnych projektów finansowanych ze środków UE;

c) wspieranie wymiany gospodarczej, społecznej, kulturalnej, turystycznej, sportowej, oświatowej i naukowej;

d) wspieranie działań samorządów lokalnych oraz instytucji pozarządowych w nawiązywaniu współpracy międzyregionalnej;

e) działalność Biura Regionalnego Województwa Podlaskiego w Brukseli;

f) promocję regionu poza granicami kraju;

g) utrzymywanie i rozwijanie kontaktów z Polonią.

Uchwała określa geograficzne kierunki prowadzenia aktywności zewnętrznej oraz definiuje zasady udziału województwa w instytucjach i stowarzyszeniach międzynarodowych. Znajdują się w niej również zapisy dotyczące kontynuacji współdziałania w ramach już zawartych porozumień o współpracy i deklaracji partnerstwa, a także uczestnictwa w organizacjach i instytucjach międzyregionalnych.

Województwo może również przystępować do międzynarodowych zrzeszeń społeczności lokalnych i regionalnych. Kwestia ta uregulowana została w Ustawie z dnia 15 września 2000 r. o zasadach przystępowania jednostek samorządu terytorialnego do międzynarodowych zrzeszeń społeczności lokalnych i regionalnych. ${ }^{278}$

276 Dz.U. z 2001 r. Nr 142, poz. 1590

277 Tryb dostępu: http://bit.ly/UTrTYI, dnia 12.12.2012 r.

278 Dz.U. z 2000 r. Nr 91, poz. 1009. 
Ostatnią z możliwych form współpracy zewnętrznej województwa jest inicjatywa zagraniczna. Określenie to zostało użyte w art. 77 ust. 1 Ustawy o samorządzie województwa i zgodnie z jego postanowieniami obejmuje w szczególności umowy o współpracy regionalnej. Wydaje się, że wprowadzając ten przepis w tak otwartym kształcie, ustawodawca chciał pod tym pojęciem umieścić wszelkie możliwe przejawy aktywności międzynarodowej województwa poza tymi wyraźnie wymienionymi w Ustawie o samorządzie województwa. Dowodzi tego również dotychczasowa interpretacja tego pojęcia i praktyka w tym zakresie stosowana przez Ministerstwo Spraw Zagranicznych. MSZ stoi na stanowisku, że każde przedsięwzięcie zagraniczne województwa, począwszy od działań o charakterze intencyjnym, poprzez składanie wniosków o dofinansowanie z funduszy współpracy transgranicznej, a na umowach o współpracy skończywszy, wymaga zgody MSZ. Tak szeroka i otwarta interpretacja pojęcia ,inicjatywa zagraniczna” powoduje w praktyce szereg utrudnień, a w niektórych przypadkach może prowadzić do paraliżu aktywności zagranicznej województwa. Kwestia ta poruszona została przez Konwent Marszałków Województw RP, który w swoim stanowisku z dnia 17 kwietnia 2012 r. ${ }^{279}$ przyjętym podczas posiedzenia w Łańcucie-Nowej Wsi, wezwał MSZ do uporządkowania stosowania określenia ,inicjatywa zagraniczna” oraz stosowania węższej interpretacji tego pojęcia.

W ostatnim okresie daje się zauważyć zmianę podejścia MSZ do aktywności zewnętrznej województw. Wydaje się, że MSZ odchodzi od dotychczasowego zachowawczego stanowiska oraz polityki ścisłej kontroli, a zaczyna postrzegać działalność zewnętrzną województw jako narzędzie prowadzenia polityki zagranicznej państwa. W swoim wystąpieniu podczas konferencji na temat obywatelskiego i samorządowego wymiaru polskiej polityki zagranicznej, która odbyła się 20 kwietnia 2012 r. w Warszawie, Minister Spraw Zagranicznych RP Radosław Sikorski powiedział280: Czy dyplomacja tradycyjna mogłaby rościć sobie pretensje do monopolu na stosunki zewnętrzne - w dobie globalizacji, ,efektu CNN”, w dobie otwartych granic, wspólnego rynku pracy czy edukacji? W sytuacji kiedy mimo oficjalnego przedstawicielstwa Polski przy Unii Europejskiej do Brukseli swoich przedstawicieli deleguje 17 polskich regionów? Stawiam oczywiście pytania retoryczne. Postawa na zasadzie ,my - czyli MSZ - wiemy lepiej” byłaby sprzeczna ze zdrowym rozsąkiem. Minister Sikorski dodał również: Chcemy czerpać z przykładów partnerskiej wspótpracy administracji państwowej ze społeczeństwem obywatelskim w innych krajach. Niech przykładem będa wzorce ze Szwecji, gdzie wspótpraca tamtejszego MSZ z samorządami ma dtuga tradycję. Te deklaracje dają powody, aby sądzić, że

279 Stanowisko Konwentu Marszałków Województw RP z dnia 17 kwietnia 2012 r. w sprawie współdziałania administracji rządowej oraz województw w zakresie inicjatyw współpracy międzynarodowej. Tryb dostępu: http://www. zwrp.pl/index.php?option=com_content\&task=view\&id=9004\&ltemid=145, dnia12.12.2012 r. 280 Polska polityka zagraniczna. Perspektywa samorządów i obywateli, Warszawa 2012, s. 4-6, tryb dostępu: http://
msz.gov.pl/resource/e53ba3e8-cc81-408c-9882-8b9082bed2d3:JCR, dnia12.12.2012 r. 
współpraca na linii MSZ - jednostki samorządu terytorialnego stanie się ściślejsza i lepiej skoordynowana w celu prowadzenia skuteczniejszej polityki zagranicznej państwa.

Zgodnie z powyższym należy podkreślić, iż jednostki samorządu terytorialnego na mocy przepisów uprawnione są do prowadzenia współpracy zagranicznej, atrybutem zaś Rady Ministrów jest prowadzenie polityki zagranicznej za pośrednictwem Ministra Spraw Zagranicznych. Oczywista różnica pomiędzy prowadzeniem polityki zagranicznej a współpracą zagraniczną kształtuje działania podejmowane przez samorządy. Aktywność zagraniczna województwa musi być spójna z priorytetami polskiej polityki zagranicznej, a co więcej, musi wspierać jej założenia poprzez oddolne działania wzmacniające pozycję całego kraju na arenie międzynarodowej. Coraz większa aktywność regionów w kontaktach zagranicznych, i to nie tylko z najbliższymi sąsiadami czy państwami Unii Europejskiej, powoduje, że w istotny sposób wpływa na kształtowanie wizerunku całego kraju.

Struktura współpracy zagranicznej prowadzonej przez województwo podlaskie opiera się na trzech modelach: współpraca podejmowana na podstawie porozumień zawartych pomiędzy władzami regionalnymi, współpraca w ramach zrzeszeń społeczności lokalnych i organizacji międzynarodowych a także współpraca niesformalizowana podejmowana na potrzeby konkretnych działań, które nie wywierają skutków długofalowych. Każdy z tych modeli pozwala na podejmowanie inicjatyw dążących do realizacji celów określonych w Priorytetach współpracy zagranicznej województwa podlaskiego.

\section{Wybrane przykłady aktywności zagranicznej województwa podlaskiego}

Poniższe przykłady aktywności zagranicznej województwa podlaskiego zostały wybrane ze względu na ich charakterystyczną i wyjątkową konstrukcję, nie stanowią zatem zamkniętego katalogu działań jakie podejmowane są przez województwo podlaskie.

\subsection{Współpraca $\mathrm{z}$ partnerami francuskimi}

Klasycznym przykładem regionalnej aktywności zagranicznej jest współpraca województwa podlaskiego z Departamentem Saône-et-Loire we Francji. Została ona zainicjowana przez Fundację FRANCE-POLOGNE i Stowarzyszenie AEP „Les Campanettes" (ośrodek jeździecki) działające na terenie Departamentu Saône-et-Loire oraz Departamentu Jura (Porozumienie o współpracy pomiędzy województwem suwalskim a Departamentem Jura z 22 listopada 1995 roku). Od początku współpraca międzyregionalna koncentrowała się na jasno sprecyzowanej tematyce, a mianowicie rozwijaniu potencjału turystycznego województwa. 
Pierwsze wspólne inicjatywy podejmowane od 1999 roku dotyczyły głównie wykorzystania doświadczeń kluczowego partnera francuskiego, Stowarzyszenia AEP „Les Campanettes” poprzez realizację projektów stażowych i szkoleniowych sprzyjających rozwojowi lokalnemu ze szczególnym uwzględnieniem turystyki aktywnej, zwłaszcza jeździeckiej; projekty obejmowały wymianę kadry specjalistów i młodzieży. Podstawę tych działań stanowiły analizy przeprowadzone na obszarze powiatu białostockiego, które wykazały potrzebę kształcenia zawodowego młodzieży z zakresu turystyki aktywnej i tym samym zwalczania bezrobocia w środowisku wiejskim (klasa o profilu: „Hodowca koni” w ówczesnym Zespole Szkół Mechanizacji Rolnictwa w Supraślu).

Mając na uwadze rozwój gospodarczy, turystyczny i kulturowy tej części regionu, w 2003 roku województwo podlaskie podpisało protokół współpracy z Radą Generalną Departamentu Saône-et-Loire obejmujący m.in. utworzenie „Regionalnego Centrum Kształcenia w zakresie Turystyki Aktywnej” (obecnie: Powiatowy Ośrodek Sportu i Rekreacji „Bukowisko” w Supraślu). Należy podkreślić, że Centrum, wyposażone m.in. w krytą ujeżdżalnię koni, powstało w 2006 roku przy udziale środków finansowych Unii Europejskiej (ZPORR w Województwie Podlaskim), Ministerstwa Spraw Zagranicznych Republiki Francuskiej oraz powiatu białostockiego. Wkład merytoryczny wnieśli również partnerzy francuscy reprezentujący Stowarzyszenie AEP „Les Campanettes” oraz Centrum Przyrodnicze EDEN z Cuisery.

Przykład utworzenia Centrum jest wzorem współpracy partnerów publicznych, rządowych i samorządowych, jak również innych aktorów instytucjonalnych i stowarzyszeń reprezentujących obie strony. Ponadto uwagi wymaga spójność wykorzystania środków przeznaczonych zarówno na wspólne działania tzw. „twarde” (środki EFRR) obejmujące powstanie Centrum, jak i działania „miękkie” (środki programów „Leonardo da Vinci” i „Młodzież w działaniu”) pozwalające na prowadzenie w nim specjalistycznej edukacji zarówno formalnej jak i nieformalnej.

Kolejnym ważnym krokiem na drodze intensyfikowania relacji z partnerem francuskim było sformalizowanie współpracy pomiędzy powiatem białostockim (województwo podlaskie) a Pays de la Bresse Bourguignonne (Departament Saône-et-Loire) poprzez podpisanie deklaracji współpracy z 16 lipca 2009 roku. Poza oświadczeniem Stron dotyczącym wzajemnego współdziałania w zakresie rozwoju gospodarczego i kulturalnego, turystyki aktywnej, jak również promocji bioróżnorodności obu obszarów, zawierała ona istotny zapis podkreślający poparcie Stron na rzecz projektów współpracy realizowanych przez LGD Puszcza Knyszyńska oraz GAL du Pays de la Bresse Bourguignonne (Lokalna Grupa Działania obejmująca obszar Pays de la Bresse Bourguignonne).

26 listopada 2010 roku w Supraślu LGD Puszcza Knyszyńska oraz GAL du Pays de la Bresse Bourguignonne podpisały deklarację woli współpracy międzyna- 
rodowej w ramach osi IV LEADER, w której sygnatariusze potwierdzili wolę przygotowania, realizacji i oceny projektu współpracy międzynarodowej. Celem ogólnym pierwszego wspólnego projektu jest zwiększenie atrakcyjności turystycznej obu obszarów. Projekt ten będzie realizowany do końca 2013 roku.

Współpraca województwa podlaskiego z Departamentem Saône-et-Loire jest klasycznym przykładem współdziałania partnerów wynikającego z potrzeby oddolnej mieszkańców regionu, ale oficjalnie zainicjowanej na szczeblu władz regionalnych. Sformalizowanie współpracy stanowiło impuls do prowadzenia konkretnych działań na niższych szczeblach samorządu, w tym przypadku na poziomie powiatu białostockiego oraz Lokalnej Grupy Działania Puszcza Knyszyńska wraz z należącymi do niej gminami, wśród których należy wymienić Supraśl, Wasilków, Czarna Białostocka.

Nie bez znaczenia dla kształtowania relacji z partnerem francuskim było ciągłe zaangażowanie regionu jako swoistego tutora prowadzonych działań. Ściśle zidentyfikowana potrzeba współpracy zorientowana na rozwój turystyki aktywnej pozwoliła na efektywne wykorzystanie bogatego doświadczenia partnera francuskiego oraz na stworzenie spójnej strategii współpracy z Departamentem Saône-et-Loire. Aktualnie tematyka współpracy poszerzana jest o nowe aspekty turystyki aktywnej oraz kwalifikowanej, jak na przykład udział w ruchu turystycznym osób niepełnosprawnych. Dużą uwagę poświęca się dostosowaniu infrastruktury turystycznej oraz szlaków turystycznych do potrzeb tej grupy uczestników.

Współpraca województwa podlaskiego z partnerami francuskimi jest doskonałym przykładem uwrażliwienia władz regionu na potrzeby aktorów lokalnych. W tym przypadku, dzięki stosownym porozumieniom, władze samorządowe stworzyły skuteczne ramy współpracy, gwarantujące spójność działań podejmowanych przez strony. Przekłada się to na efektywne wykorzystywanie środków przeznaczanych na wspólne projekty, a tym samym oddziaływanie na lokalny rozwój gospodarczy. Synergia działań podejmowanych w ramach współpracy zagranicznej z Francją przez władze samorządowe każdego szczebla przynosi wymierne efekty dla rozwoju regionu i jego mieszkańców.

\subsection{Dom Polski Wschodniej w Brukseli}

Zupełnie innym przykładem prowadzonej aktywności zagranicznej województwa jest działalność Domu Polski Wschodniej w Brukseli. Wspólna inicjatywa pięciu województw Polski wschodniej: podlaskiego, warmińsko-mazurskiego, podkarpackiego, lubelskiego i świętokrzyskiego miała na celu stworzenie silnej reprezentacji tej części Polski na arenie europejskiej w bezpośrednich kontaktach z instytucjami unijnymi. W grudniu 2008 roku na posiedzeniu Komisji Polski Wschodniej Związku Województw Rzeczypospolitej Polskiej, marszałkowie pięciu województw przyjęli wspólne stanowisko o powołaniu wspólnego przedstawicielstwa w Bruk- 
seli. Na mocy Porozumienia z 2009 roku $^{281}$ województwa Polski wschodniej, objęte wspólnym programem Rozwój Polski Wschodniej, borykające się z podobnymi problemami rozwojowymi i charakteryzujące się podobnym potencjałem, zostały wyposażone w dodatkowy instrument sprzyjający wzmacnianiu ich pozycji.

Zgodnie z ustaleniami wypracowano najbardziej efektywną formułę funkcjonowania wspólnego przedstawicielstwa w Brukseli, która odpowiada sprawdzonemu europejskiemu modelowi polegającemu na skupieniu kilku regionów pod jednym szyldem, dobrym przykładem takiej współpracy może być Dom Szkocki. Połączenie większej liczby regionów sprzyja lepszej, silniejszej i bardziej widocznej reprezentacji na arenie europejskiej, umożliwia skuteczniejszy lobbing przed instytucjami europejskimi i lepszą promocję.

Celem Porozumienia było skoordynowanie działań oraz określenie głównych zasad funkcjonowania Domu. Przedstawicielstwa poszczególnych województw nie utraciły autonomii, działają na rzecz swojego regionu oraz podejmują wspólne działania w ramach Domu Polski Wschodniej. Wspólna siedziba oraz prowadzenie wspólnego sekretariatu wzmacnia pozycję wizerunkową regionów Polski wschodniej na arenie europejskiej. Ponadto Porozumienie uregulowało kadencyjną koordynację nad pracami Domu Polski Wschodniej kolejno przez każdego z marszałków. W 2013 roku koordynację prac DPW przejmuje województwo podlaskie.

Doskonałym przykładem wykorzystania tego narzędzia aktywności międzynarodowej jest podjęcie szeregu działań zmierzających do wspierania idei Partnerstwa Wschodniego jako projektu kulturowego. Rozpowszechnianie za pośrednictwem DPW dyskusji na temat kulturowego wymiaru Partnerstwa Wschodniego oraz propagowanie rekomendacji z pierwszego Kongresu Kultury Partnerstwa Wschodniego, który odbył się w dniach 21-23 października 2011 roku w Lublinie w realny sposób kształtuje strategię współpracy z krajami objętymi Partnerstwem. Trwają prace nad przyjęciem wspólnego Stanowiska Województw Polski Wschodniej w sprawie kulturowego wymiaru Partnerstwa Wschodniego, którego celem jest między innymi: wypracowanie nowych form współpracy kulturalnej z krajami objętymi inicjatywą Partnerstwa Wschodniego, włączenie podmiotów z krajów objętych inicjatywą Partnerstwa Wschodniego w prace nad kształtem europejskiej polityki sąsiedztwa oraz zbudowanie sieci wspierającej organizacje i twórców z tych krajów, podjęcie działań zmierzających do podniesienia efektywności już istniejących mechanizmów finansowania kultury w krajach objętych inicjatywą Partnerstwa Wschodniego i Unii Europejskiej, poprzez racjonalne wykorzystywanie środków i ich efektywniejszą alokację. Rekomendacje skierowane zostaną do organów Unii Europejskiej, administracji centralnej i lokalnej krajów objętych inicjatywą Partnerstwa Wschodniego

281 Uchwała nr XXXII/374/09 Sejmiku Województwa Podlaskiego z dnia 21 września 2009 w sprawie powierzenia zadań z zakresu prowadzenia wspólnego przedstawicielstwa województw: lubelskiego, podkarpackiego, podlaskiego, świętokrzyskiego, warmińsko-mazurskiego pod nazwą Dom Polski Wschodniej w Brukseli. 
i Unii Europejskiej, a w szczególności do instytucji odpowiedzialnych za kulturę, edukację i ich finansowanie, a także do organizacji kulturalnych, uniwersytetów oraz środowisk twórczych.

\subsection{Konferencja Peryferyjnych Regionów Nadmorskich}

Województwo podlaskie jest członkiem Konferencji Peryferyjnych Regionów Nadmorskich (Conference of Peripheral Maritime Regions - CPMR) od 2002 r. ${ }^{282}$ CPMR to stowarzyszenie międzyregionalne, które powstało w $1973 \mathrm{r}$. i obecnie skupia ponad 160 regionów z 28 państw europejskich. Główne cele działalności CPMR obejmują: ograniczenie negatywnych skutków peryferyjnego położenia regionów członkowskich poprzez promowanie ich rozwoju, lepsze wykorzystanie atutów regionów członkowskich poprzez ich współpracę w ramach wspólnych projektów, wykorzystanie korzyści płynących z bliskości władz regionalnych względem obywateli. Konferencja reprezentuje wspólne interesy regionów członkowskich, głównie wobec instytucji UE. CPMR proponuje konkretne rozwiązania w zakresie polityk wspólnotowych mających wpływ terytorialny, a mianowicie: polityki regionalnej, zrównoważonego rozwoju, transportowej, rolnej, konkurencji, badań i rozwoju oraz rybołówstwa. Dzięki wysokiemu poziomowi merytorycznemu proponowanych rozwiązań CPMR jest organizacją wysoce cenioną w Brukseli i stanowi skuteczne forum lobbingowe.

Województwo podlaskie jest, jak dotąd, jest jedynym polskim regionem należącym do CPMR. W ramach uczestnictwa w Konferencji województwo skupia się szczególnie na zagadnieniach dotyczących polityki spójności oraz polityki regionalnej UE, transportu (ze szczególnym uwzględnieniem sieci TEN-T), zatrudnienia i szkoleń. Region jest ponadto aktywnym promotorem idei Partnerstwa Wschodniego oraz polityki sąsiedztwa UE.

Można stwierdzić, że województwo podlaskie jest najbardziej aktywnym regionem członkowskim CPMR spośród państw tzw. nowej Unii Europejskiej. Region dał się poznać jako aktywny, rzetelny i godny zaufania członek organizacji, czego wyrazem było powierzenie Podlaskiemu organizacji Zgromadzenia Ogólnego CPMR w październiku 2012 r., które odbyło się w Białymstoku i zgromadziło ponad 300 uczestników, w tym członków przedstawicieli rządów państw członkowskich UE, członków Komisji Europejskiej i posłów do Parlamentu Europejskiego.

Podsumowując, należy podkreślić, iż podejmowanie aktywności zagranicznej przez województwo podlaskie jest nieodzownym elementem jego rozwoju. Biorąc pod uwagę obecną politykę Unii Europejskiej, podstawowym wymogiem harmonijnego wzrostu jest powstanie sieci międzyregionalnych powiązań, służących inte-

Podstawę członkostwa województwa w CPMR stanowi Uchwała Nr XLVIII/389/02 Sejmiku Województwa Podlaskiego z dnia 26 lutego 2002 r. w sprawie przystąpienia Województwa Podlaskiego do międzynarodowej organizacji CPMR. 
resom wszystkich aktorów, wyrównywaniu różnic w rozwoju między silnymi i peryferyjnymi regionami. Dlatego też województwo podlaskie angażuje się zarówno we współpracę międzyregionalną z partnerami z krajów Unii Europejskiej, nie zapominając jednak o żywej potrzebie kontaktów z najbliższymi sąsiadami i krajami Partnerstwa Wschodniego, które ze względu na nasze położenie geograficzne przyjmują strategiczny charakter. 


\section{EXTERNAL RELATIONS OF PODLASKIE VOIVODSHIP}

The article focuses on international and inter-regional activities of the Polish region of Podlaskie. It presents the statutory regulations concerning external relations of Polish local and regional authorities. With Poland being a unitary state, the article discusses practical aspects of conducting regional external co-operation in line with the principles of the state's foreign policy. The authors outline the priorities of Podlaskie's external activities, as adopted by the Regional Assembly (Sejmik), and provide an insight into selected examples of inter-regional co-operation.

Keywords:

External relations, Podlaskie, priorities of external activities, local and regional authorities 